\title{
APPLICATION OF FEDERAL ACCOUNTING STANDARDS IN AGRICULTURAL ORGANIZATIONS
}

\author{
Irina D. Anikina \\ Volgograd State University, Volgograd, Russian Federation \\ Svetlana V. Solodova \\ Volgograd State University, Volgograd, Russian Federation
}

\begin{abstract}
The article substantiates the importance of agro-industrial enterprises, their products and the economic effect produced in the development of economy of the Russian Federation. The stages of reforming the regulatory control of accounting in the Russian Federation are disclosed. The article describes the current state of accounting modernization in agricultural organizations. The necessity of creating a methodological base for accounting by agricultural producers is justified. The possible directions of constructing and developing a methodological base for the organization of accounting in agricultural enterprises are revealed. The formation of accounting policies in accordance with the amended Russian Accounting Standards (RAS) and the new Federal Accounting Standards (FAS) requires a comprehensive approach and algorithmization of activities, dividing them into blocks or stages. The algorithm of implementing new Federal Accounting Standards for agricultural organizations in the accounting process is defined. Document forms that allow following the proposed algorithm for implementing new Federal Accounting Standards in the accounting process have been developed. Separate issues of application of the Federal Accounting Standard "Inventories" are considered. The necessity to determine the order of accounting objects of accounting supervision before the introduction of new standards into effect is justified in order to optimally implement the Standards in the practice of organizations.

Key words: economy and management of agriculture, development of information and advisory systems in the agro-industrial complex, Federal Accounting Standards.

Citation. Anikina I.D., Solodova S.V. Application of Federal Accounting Standards in Agricultural Organizations. Journal of Volgograd State University. Economics, 2020, vol. 22, no. 2, pp. 201-212. (in Russian). DOI: https://doi.org/ 10.15688/ek.jvolsu.2020.2.19
\end{abstract}

\section{ПРИМЕНЕНИЕ ФЕДЕРАЛЬНЫХ УЧЕТНЫХ СТАНДАРТОВ В СЕЛЬСКОХОЗЯЙСТВЕННЫХ ОРГАНИЗАЦИЯХ}

\author{
Ирина Дмитриевна Аникина \\ Волгоградский государственный университет, г. Волгоград, Российская Федерация \\ Светлана Викторовна Солодова \\ Волгоградский государственный университет, г. Волгоград, Российская Федерация
} Аннотация. В статье обосновано значение предприятий агропромышленного комплекса, их продук-
ции и производимого экономического эффекта в развитии экономики Российской Федерации. Раскрыты
этапы реформирования нормативного регулирования бухгалтерского учета в Российской Федерации. Дана
характеристика текущему состоянию модернизации бухгалтерского учета в организациях сельского хозяй-
ства. Обоснована необходимость создания методической базы для ведения бухгалтерского учета производи- 
телями сельскохозяйственной продукции. Выявлены возможные направления построения и развития методической базы организации бухгалтерского учета в сельскохозяйственных предприятиях. Формирование учетной политики в соответствии с измененными ПБУ и новыми ФСБУ требует комплексного подхода и алгоритмизации деятельности, разделения ее на блоки или этапы. Определен алгоритм реализации в учетном процессе новых федеральных стандартов бухгалтерского учета для сельскохозяйственных организаций. Разработаны формы документов, позволяющие осуществить предложенный алгоритм реализации в учетном процессе новых федеральных стандартов бухгалтерского учета. Рассмотрены отдельные вопросы применения федерального стандарта бухгалтерского учета «Запасы». Обоснована необходимость до введения новых стандартов в действие определить порядок учета объектов бухгалтерского наблюдения, чтобы оптимально внедрить Стандарты в практику организаций.

Ключевые слова: экономика и управление сельским хозяйством, развитие информационно-консультативных систем в АПК, федеральные стандарты бухгалтерского учета.

Цитирование. Аникина И. Д., Солодова С. В. Применение федеральных учетных стандартов в сельскохозяйственных организациях // Вестник Волгоградского государственного университета. Экономика. - 2020. T. 22, № 2. - C. 201-212. -DOI: https://doi.org/10.15688/ek.jvolsu.2020.2.19

\section{Введение}

Предприятия агропромышленного комплекса, их продукция и производимый экономический эффект представляют собой мощный потенциал развития экономики России. Занимаемая площадь, разнообразие климатических поясов и погодных условий обеспечивают возможность выращивания разнообразной растениеводческой и животноводческой продукции. Аграрный потенциал России обеспечивает возможность не только полного обеспечения населения продуктами собственного производства, но и успешное проникновение на внешний рынок.

Международная экономическая интеграция предполагает процесс экономического взаимодействия стран. Основными признаками международной экономической интеграции можно определить следующие процессы:

- взаимопроникновение национальных экономических процессов;

- широкое развитие специализации производства в международных экономических отношениях;

- влияние экономической интеграции на структурные изменения в экономике странучастниц;

- координация стратегии экономического развития стран-участниц как целенаправленное регулирование интеграционного процесса.

Исследуя процедуру экономического сближения стран, необходимо отметить один из существенных моментов. Всем известно, что при ведении переговоров, как минимум, необходимо иметь возможность общаться на каком-либо одном языке, который понимает каждая из участвующих сторон. При решении вопросов об экономическом взаимодействии не менее важно, чтобы участники понимали экономическую информацию, представленную другой стороной. В рамках решения данной задачи мы сталкиваемся с целым рядом проблем.

1. Идентификация категориального аппарата участников.

Определить экономическую категорию и найти в иностранном языке соответствующее ей определение - достаточно сложная задача даже для грамотного экономиста.

2. Выявление или разработка экономических показателей, органично вписывающихся в систему финансовой отчетности каждого из участников.

Под одним и тем же показателем (названием) стороны могут понимать несколько разные величины. В связи с этим возникает третья проблема.

3. Разработка алгоритма исчисления показателей деятельности, которые лягут в основу создания совместных планов регулирования хозяйственного процесса, формирования отчетности.

Данная проблема, в сущности, состоит в том, что одни и те же показатели (исходя из их названия) в разных странах могут исчисляться несколько по-разному.

Решение указанной проблемы лежит в области регулирования финансов и бухгалтерского учета.

Исходя из вышеизложенного, одним из важнейших условий развития и совершен- 
ствования международных экономических отношений становится сближение требований, предъявляемых к информации, формирующейся в бухгалтерском учете. И такая работа в нашей стране ведется уже достаточно давно.

\section{Методика}

Официальным началом процесса реформирования учета в России следует считать принятие в 1992 г. Государственной программы перехода Российской Федерации на принятую в международной практике систему учета и статистики. К 2015 г. планировалось привести национальные стандарты в полное соответствие с Международными стандартами, однако на сегодняшний день на сайте министерства финансов Российской Федерации представлено 25 действующих стандартов, кроме того, здесь же расположен перечень федеральных стандартов бухгалтерского учета (ФСБУ), находящихся на различных стадиях разработки и внесения изменений.

Пять ФСБУ уже разработаны и должны вступить в силу с 1 января 2021 г.: «Запасы», «Нематериальные активы», «Основные средства», «Незавершенные капитальные вложения», «Документы и документооборот в бухгалтерском учете». Еще два стандарта: «Некоммерческая деятельность» и «Бухгалтерская отчетность» с 2021 г. также должны начать действовать. Однако на август 2020 г. разработка данных стандартов еще не завершена, и это при том, что срок представления уведомления о разработке проекта стандартов был определен как II квартал 2019 г., а срок представления проекта стандартов в Совет по стандартам бухгалтерского учета как IV квартал 2019 года. Четыре стандарта должны быть введены в действие с 2022 г.: «Доходы», «Участие в зависимых организациях и совместная деятельность», «Финансовые инструменты», «Долговые затраты». По первым двум из них так же, как и по вышеперечисленным, наблюдается несоблюдение сроков представления. Проекты последних двух стандартов должны быть представлены соответственно в III квартале 2020 г. и I квартале 2021 года. Представленные выше сроки были утверждены приказом Министерства финансов Российской Федерации от 5 июня 2019 г. № 83 н.

Из представленной информации видно, что разработка стандартов бухгалтерского учета в Российской Федерации представляет собой достаточно длительный процесс. Ряд стандартов, будучи утверждены достаточно давно, претерпели ряд более или менее существенных изменений, которые по существу изменили, частично или полностью, первоначальный смысл и логику стандарта.

Особое значение государственное нормативное регулирование бухгалтерского учета имеет для сельскохозяйственных предприятий. Авторы данного исследования показали необходимость внесения изменений в ФСБУ «Запасы» на примере предприятий АПК [Солодова и др., 2020]. Также вопросы совершенствования отражения в учете и отчетности информации о сельскохозяйственной деятельности изучали такие ученые, как Р.А. Алборов [Alborov et al., 2019], В.В. Башкатов [Башкатов, 2018], В.С. Германова [Германова, 2018], Н.В. Кулиш [Кулиш, 2018], Л.В. Попова, П. Холмер [Попова и др., 2018], Г.В. Федотова [Федотова др., 2019], И.А. Яценко [Яценко, 2014], Л.И. Хоружий [Хоружий и др., 2019].

Осуществление деятельности, связанной с производством сельскохозяйственной продукции, представляется достаточно специфическим и требующим организации учета объектов, не характерных для иных производств. В процесс производства сельскохозяйственной продукции входит существенное число факторов, наличие которых имеет несколько неопределенный характер, но которые, тем не менее, необходимо отразить в учете и принять во внимание при оценке деятельности предприятия.

Начать необходимо с того, что сама отрасль «сельское хозяйство» весьма многоплановая. Основные направления деятельности сельскохозяйственных предприятий - это растениеводство и животноводство. Каждое из данных направлений включает в себя множество подотраслей, каждая из которых имеет свои характерные особенности, предопределяющие продолжительность производственного цикла, уровень и структуру затрат, уровень автоматизации хозяйственных процессов, наличие отходов и потерь. Все эти 
факторы диктуют порядок организации бухгалтерского учета. Кроме животноводства и растениеводства к организациям агропромышленного комплекса относятся предприятия, занятые рыбоводством, перерабатывающая промышленность, имеющие свои специфические особенности.

Существующее нормативное регулирование на уровне государственных стандартов не может со всей определенностью диктовать порядок организации учета в условиях хозяйственной деятельности определенного сельскохозяйственного предприятия. Ответственно можно говорить о необходимости создания методической базы для ведения бухгалтерского учета сельскохозяйственными производителями. Существует три направления построения и развития методической базы.

Первое направление строится на том, что в соответствии с Законом 402-ФЗ «О бухгалтерском учете» нормативные документы по бухгалтерскому учету должны включать отраслевые стандарты бухгалтерского учета, определяющие порядок организации учета специфичных отраслевых объектов бухгалтерского, в частности, для отрасли «сельское хозяйство». Это направление предполагает, что разработкой отраслевых стандартов будут заниматься соответствующие министерства. Такой порядок нормативного регулирования представляется оптимальным. Положительной стороной такого решения проблемы является унификация учетного процесса для типичных объектов, характерных для данной отрасли. Выделяемые министерством средства могут позволить провести разработку отраслевого стандарта на достаточно высоком профессиональном, научном и методическом уровнях.

Препятствием на пути следования по указанному пути является нестабильность, изменчивость существующих федеральных стандартов. Поскольку отраслевые стандарты, являясь нормативными документами более низкого уровня по отношению к федеральным стандартам, не могут им противоречить, возникает необходимость пересмотра отраслевых стандартов всякий раз, когда изменения вносятся в федеральные стандарты. При этом один федеральный стандарт вполне может затронуть несколько отраслевых. Посто- янная работа по обновлению методических указаний потребует от министерства сельского хозяйства значительных трудовых, финансовых и материальных затрат.

Второе направление заключается в том, что работа по методическому обеспечению учетного процесса может быть перенесена в полном объеме на конечного исполнителя непосредственно на бухгалтера, обеспечивающего ведение учета в условиях хозяйствования конкретного предприятия. Такое решение проблемы имеет то преимущество, что на его осуществление не требуется затрат бюджета.

Лицам, на которых возлагаются обязанности по формированию учетной политики, необходимо будет во внутренних (локальных) нормативных документах прописать порядок отражения в учете отдельных видов активов, обязательств и фактов хозяйственной жизни. Ответственность за соответствие принятой методики требованиям федерального стандарта ложится полностью на бухгалтера организации. Дополнительные средства на разработку методики не требуются. Вся работа осуществляется в рамках должностных обязанностей бухгалтера. Как вариант, может быть приглашен аудитор или представитель аутсорсинга, который предложит методику, наиболее приемлемую для данной организации. В данном случае расходы ложатся на собственника сельскохозяйственной организации.

Данный вариант имеет ряд недостатков. В частности, уровень квалификации учетных работников, осуществляющих учет в сельскохозяйственных предприятиях, довольно часто не позволяет разработать методику учета. Если даже учетным работником разработана методика, полностью соответствующая требованиям стандарта, этого бывает недостаточно, поскольку учет в настоящее время ведется исключительно на компьютере. Базовые настройки стандартных учетных программ обеспечивают соответствие требованиям только федеральных стандартов. Возникает необходимость доработки программного обеспечения в соответствии с разработанной методикой. На данном этапе важным становится факт полного взаимопонимания бухгалтера и программиста, без которого ни одна идея в области бухгалтерского учета в 
организации не может быть реализована. При этом существенное значение будет иметь не только квалификация бухгалтера, но и квалификация программиста. Понятно, что работа по обеспечению методики, выполненная на уровне хозяйствующего субъекта, далеко не всегда будет выполнена идеально.

Третье направление, к сожалению, выглядит наиболее реалистичным. Наибольшая вероятность развития событий в области формирования отраслевых стандартов заключается в совмещении первых двух направлений. Поскольку наличие отраслевых стандартов определено Законом, работа в данном направлении будет вестись. Министерство будет выделять средства на их разработку. В дальнейшем, при внесении изменений в федеральные стандарты, потребуется изменение и стандартов отраслевых. И опять будут выделяться деньги. В то же время практика показала, что отраслевые министерства не склонны глубоко вникать в проблемы организации учета специфических, сложных для организации учета, объектов. Велика вероятность того, что так называемый отраслевой стандарт будет максимально дублировать федеральный стандарт, не раскрывая в необходимой мере специфику сельскохозяйственного производства. Возможно, будет дана ссылка на грядущие методические указания, либо методические рекомендации. Но формирование данных документов возможно только после создания отраслевого стандарта. Таким образом, непосредственное методическое обеспечение учетного процесса опять ложится на непосредственного исполнителя.

\section{Результаты и обсуждение}

Из вышесказанного следует, что практикующим бухгалтерам нужно уже сейчас задумываться об оптимальной организации учетного процесса в условиях действия новых федеральных стандартов бухгалтерского учета.

Процесс организации учетного процесса в сельскохозяйственных организациях усложняется в результате наличия специфических активов, порядок учета которых не определен действующими стандартами. Внесение постоянных изменений в учетные стандарты не позволяет достаточно быстро и эффективно вносить в учетную политику корректировки, обусловленные изменениями федеральных учетных стандартов.

Учетная политика разрабатывается на перспективу, однако, как правило, субъекты, формирующие отчетность, утверждают новую учетную политику или пролонгируют действие старого приказа ежегодно. Ежегодно накапливается новая информация, которую необходимо учитывать при формировании учетной политики на следующий финансовый год. Необходимость формирования учетной политики не отменяет текущих дел, которые отнимают время и занимают внимание главного бухгалтера.

В результате отсутствия единой системы координирования процесса формирования учетной политики отдельные вопросы, которые в связи с принятием тех или иных нормативных документов должны быть прописаны в учетной политике, остаются без внимания.

К формированию учетной политики существуют два подхода, имеющие принципиальные различия. Один из них состоит в том, что формирование учетной политики осуществляется как разовый акт, проводимый в конце финансового года, или в начале следующего. Ответственный работник осуществляет формирование учетной политики на основе старого приказа с учетом изменений, произошедших за год. Такой подход к формированию учетной политики в настоящее время наиболее используемый.

Наше предложение состоит в принципиально ином подходе к формированию учетной политике. Обилие информации, так или иначе оказывающей влияние на процесс ведения бухгалтерского учета, приводит к мысли о необходимости ее систематизации. Мы полагаем, что в основе разработки новой учетной политики должны лежать, во-первых, старый (прошлогодний) приказ об учетной политике, во-вторых, реестр документов, изменяющих порядок ведения учета, принятых в текущем году.

Принимаемые вновь документы достаточно разноплановые, в связи с чем возникает необходимость их классификации и систематизации. Не все документы, вступившие в силу в соответствующем году, будут оказывать воздействие на ведение учета в сельс- 
кохозяйственных организациях. Это также необходимо учитывать. Следовательно, на определенном этапе сбора информации должна происходить «сортировка» документов. Наконец, на основании каждого документа, оказывающего, или способного оказать воздействие на процесс ведения учета, должна быть составлена соответствующая поправка в учетную политику. Если такая работа проводится в течение года, то, с одной стороны, в конце годы мы получаем комплект поправок, готовых к внесению в учетную политику, a с другой стороны, возникает возможность часть «технической» работы переложить с руководителя бухгалтерской службы (чей труд ценится достаточно высоко) на менее квалифицированный персонал. Есть еще и третья сторона. Поскольку в разработке учетной политики участвуют представители различных подразделений бухгалтерской службы, обеспечивается своевременное ознакомление рядовых работников бухгалтерии с актуальными изменениями в нормативной базе.

Формирование учетной политики в соответствии с новыми учетными стандартами требует комплексного подхода и алгоритмизации деятельности, разделения ее на блоки или этапы. Первым этапом реализации плана формирования учетной политики является сбор информации о новых нормативных документах, затрагивающих деятельность по ведению учета и формированию отчетности. С данным видом работы может справиться любой работник бухгалтерии. Имеет смысл привлекать к данной деятельности работников, имеющих наиболее низкие квалификационные разряды.

Для формирования первичной информации о принятых нормативных документах мы предлагаем разработанную форму реестра. Пример заполнения представлен в таблице 1 .

Заполнение реестра осуществляется поэтапно. Первые пять колонок заполняются работником бухгалтерии, на которого будет возложена данная функция. В его обязанности будет входить регулярный мониторинг Интернета, в частности, сайтов Минфина РФ, ФНС и т. п.

Заместитель руководителя бухгалтерской службы или сам главный бухгалтер периодически может в колонке 6 таблицы 1 определять квалификацию данного документа, определять отдел, или конкретного работника, который будет ответственен за его обработку.

Здесь же может быть указание на неактуальность данного документа для субъекта ведения учета, пролонгация начала действия документа на следующий год и т. п. комментарии.

Руководитель бухгалтерской службы вменяет в обязанность руководителям отделов периодически, например, один раз в квартал, проводить проверку реестра на предмет наличия документов, предполагающих внесение изменений в работу соответствующего отдела. На основе проверки реестра должны быть заготовлены проекты внесения изменений в учетную политику соответствующей структуры. Если изменение, внесенное соответствующим документом, не влечет за собой изменение в учетной политике, об этом должна быть сделана соответствующая отметка. Результаты изучения нормативных документов ответственными лицами должны быть представлены в Журнале регистрации изменений ведения бухгалтерского учета. Пример заполнения Журнала представлен в таблице 2.

Реестр регистрации нормативных документов 2019 г.

\begin{tabular}{|c|c|c|c|c|c|}
\hline $\begin{array}{c}\text { № } \\
\Pi / \Pi \\
\end{array}$ & Название документа & $\begin{array}{c}\text { Утверждение } \\
\text { документа }\end{array}$ & $\begin{array}{c}\text { Дата начала } \\
\text { действия }\end{array}$ & Ссылка на сайт & Квалификация \\
\hline 1 & $\begin{array}{l}\text { «О внесении изменений в } \\
\text { части первую и вторую } \\
\text { Налогового кодекса Рос- } \\
\text { сийской Федерации» }\end{array}$ & $\begin{array}{l}\text { Федеральный за- } \\
\text { кон от 29.09.2019 } \\
\text { № 325-Ф3 }\end{array}$ & 01.01 .2020 & $\begin{array}{l}\text { http://www.consultant. } \\
\text { ru/cons/cgi/online.cgi?r } \\
\text { eq=doc\&base=LAW\& } \\
\mathrm{n}=348661 \& f l d=134 \& d \\
\mathrm{st}=1000000001,0 \& \mathrm{rnd} \\
=0.9585899097911268 \\
\# 08830362748836083\end{array}$ & $\begin{array}{l}\text { Отдел нало- } \\
\text { гообложения }\end{array}$ \\
\hline
\end{tabular}

Примечание. Составлено авторами. 
Журнал регистрации изменений ведения бухгалтерского учета

\begin{tabular}{|l|c|l|l|}
\hline \multicolumn{1}{|c|}{$\begin{array}{l}\text { Название документа } \\
\text { (сокращенное) }\end{array}$} & \multicolumn{3}{|c|}{ Изменения } \\
\cline { 2 - 5 } $\begin{array}{l}\text { Приказ ФНС России } \\
\text { от 16 июля 2020 г. } \\
\text { № ЕД-7-2/448 }\end{array}$ & 1 & $\begin{array}{l}\text { Введены правила электронного } \\
\text { обмена, по которым организации } \\
\text { и предприниматели с 30 августа } \\
\text { будут обмениваться с налоговой } \\
\text { инспекцией документацией }\end{array}$ & $\begin{array}{l}\text { Обечитье технетственные лица } \\
\text { нический отдел) }\end{array}$ \\
\hline $\begin{array}{l}\text { Письмо ФНС России средства } \\
\text { от 12 августа 2020 г. } \\
\text { № СД-4-3/12981 }\end{array}$ & 2 & $\begin{array}{l}\text { Условия применения нулевой } \\
\text { ставки налога на прибыль }\end{array}$ & $\begin{array}{l}\text { Определить принадлежность ор- } \\
\text { ганизации к льготируемым груп- } \\
\text { пам (бухгалтер по учету налогов) }\end{array}$ \\
\hline $\begin{array}{l}\text { Внесены изменения в поста- } \\
\text { новление правительства } \\
\text { от 6 апреля 1999 г. № 382 }\end{array}$ & 3 & $\begin{array}{l}\text { Уточнен перечень отраслей и ви- } \\
\text { дов деятельности сезонного ха- } \\
\text { рактера }\end{array}$ & $\begin{array}{l}\text { Определить принадлежность видов } \\
\text { деятельности организации к сезон- } \\
\text { ным (бухгалтер по учету налогов) }\end{array}$ \\
\hline
\end{tabular}

Примечание. Составлено авторами.

Если по результатам формирования журнала необходимо вносить изменения в Учетную политику, назначается лицо, ответственное за формулировку указанных изменений. Предложенные формулировки представляются руководителю отдела в письменной форме, объединяются в таблицу и представляются для утверждения руководителю бухгалтерской службы.

Общий вид алгоритма реализации в учетном процессе новых федеральных стандартов бухгалтерского учета для сельскохозяйственных организаций можно представить в виде блок-схемы (см. рисунок).

В результате применения предложенного алгоритма обеспечивается:

- высокий уровень реализации происходящих в нормативном регулировании изменений в бухгалтерском учете;

- регистрируется информация о том, на основании какого нормативного документа был внесен тот или иной пункт в учетную политику;

- документально подтверждается должностное лицо, ответственное за реализацию в учетной политике изменений порядка ведения учета;

- обеспечивается разделение обязанностей по формированию положений учетной политики между работниками бухгалтерской службы.

Использование Реестра регистрации нормативных документов и Журнала регистрации изменений ведения бухгалтерского учета позволяет осуществлять текущий кон- троль над соблюдением требований бухгалтерского учета.

Все указанные составляющие определяют более высокий уровень формирования основного локального нормативного документа по ведению бухгалтерского учета, обеспечивают его высокую информативность и полное соответствие требованиям внешних и внутренних (ведомственных) нормативных актов.

В качестве примера работы с федеральным стандартом на предприятиях АПК разберем отдельные вопросы применения ФСБУ «Запасы» [Приказ Минфина России ... , 2019]. Данный стандарт включает множество новаций, а сам объект учета - запасы актуален для сельскохозяйственных организаций. Подробный анализ ФСБУ «Запасы» представлен авторами в [Солодова и др., 2020]. Остановимся на наиболее существенных аспектах практического применения данного стандарта для предприятий АПК.

ФСБУ «Запасы» Минфин РФ утвердил в ноябре 2019 г., а применять его на практике организации начнут с 2021 года. Также с 2021 г. утрачивают силу следующие ПБУ: ПБУ 5/01 «Учет МПЗ» [Положение по бухгалтерскому учету ..., 2001]; методические указания по бухгалтерскому учету МПЗ; методические указания по учету специального инструмента, специальных приспособлений, специального оборудования и специальной одежды. За оставшееся время организациям необходимо привести свою учетную политику в соответствие с новыми требованиями к организации учета материальных ценностей, кото- 


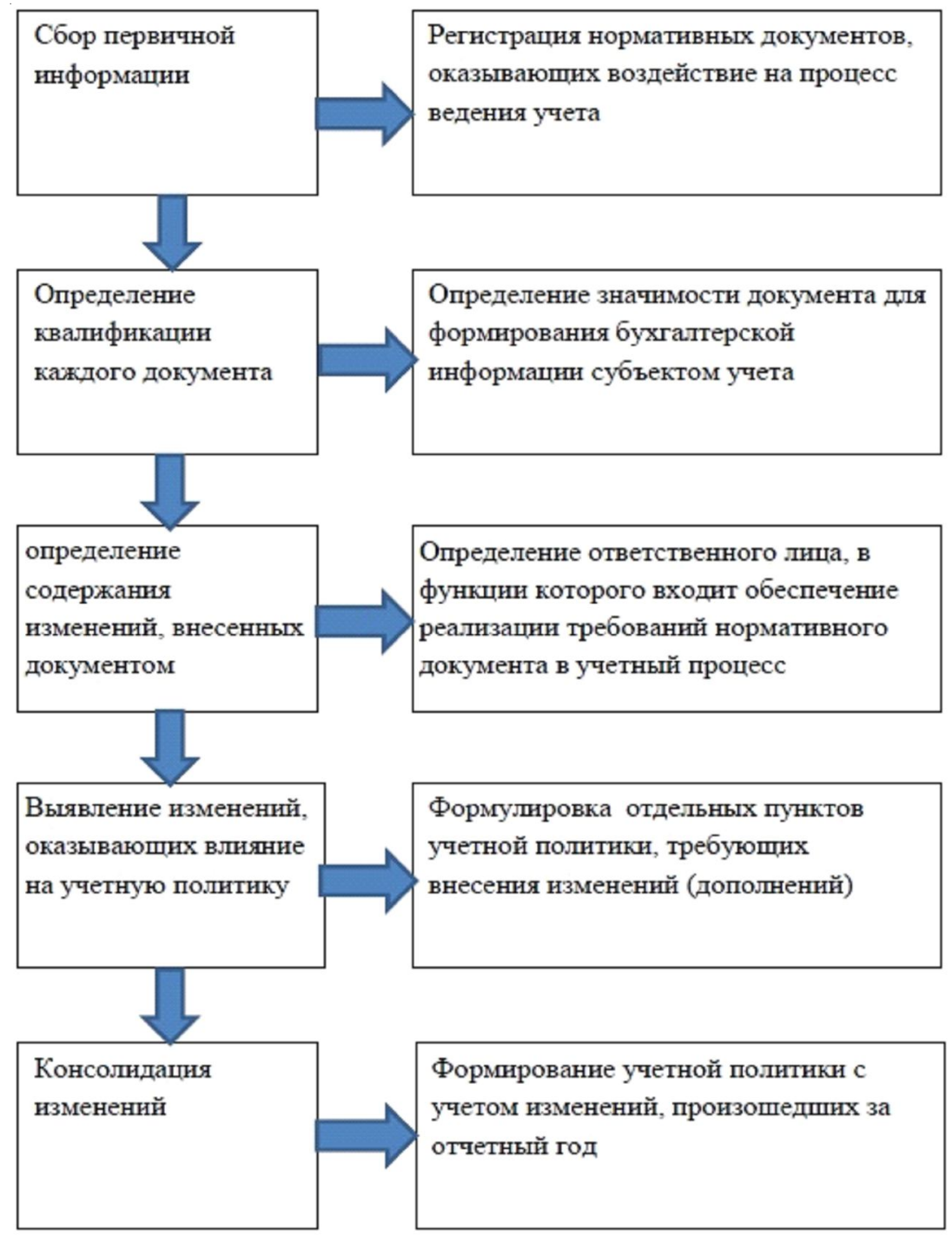

Рисунок. Алгоритм реализации в учетном процессе новых федеральных стандартов бухгалтерского учета

Примечание. Составлено авторами.

рые в значительной мере отличаются от существующей практики учета запасов. Рассмотрим данные изменения подробнее.

1. В новом стандарте в состав запасов включается незавершенное производство (НПЗ). Данное положение соответствует нормам МФСО, которые трактуют НПЗ как часть запасов. В российской практике учета НПЗ перестали выделять как отдельную статью баланса с 2011 г., а остатки по счетам производства отражаются в составе статьи баланса «Запасы».

2. ФСБУ «Запасы» включает достаточно подробный перечень объектов, которые могут быть признаны в качестве запасов (ст. 3), а также объектов, не попадающих под действие стандарта (ст. 4).
3. В стандарт включен новый раздел «Оценка после признания», которого нет в действующем ПБУ 5/01 «Учет МПЗ». Оценка после признания используется бухгалтерами на практике для внеоборотных активов и важна, поскольку длительность эксплуатации внеоборотных активов порождает расхождение между учетной и реальной стоимостью активов. Запасы характеризуются тем, что используются в течение операционного цикла (или 12 календарных месяцев), за который их стоимость не меняется достаточно сильно, в силу чего актуальность определения реальной стоимости запасов не является критичной. В новом ФСБУ данная оценка является необходимой. 
ФСБУ «Запасы» дает следующие варианты учета запасов: 1) по фактической себестоимости; 2) по чистой стоимости продажи запасов. При этом Стандарт ориентирует организации на недопущение завышения стоимости запасов в отчетности.

В п. 29 Стандарта указывается, что «предполагаемая цена, по которой организация может продать запасы в том виде, в котором обычно продает их в ходе обычной деятельности, за вычетом предполагаемых затрат, необходимых для их производства, подготовки к продаже и осуществления продажи» (см.: ФСБУ 5/2019 «Запасы», п. 29). Следовательно, чистая цена готовой продукции, рассчитанная по данной методике, будет существенно ниже фактической, так как основу фактической себестоимости готовой продукции составляют затраты на ее производство и продажу. В случае нерентабельности производства мы можем получить отрицательную стоимость запасов. Такая оценка запасов практически сведет наличные запасы любого предприятия к сумме возможной к получению прибыли. При этом данная величина будет очень приблизительной, поскольку основана на предположениях. Приведем следующий пример: «сельскохозяйственное предприятие получило готовую продукцию, фактическая себестоимость которой составила условно 100 рублей. Предполагаемая цена, по которой предприятие продает эту продукцию, например, 125 рублей. Предполагаемые расходы, связанные с продажей продукции, -5 рублей. Из текста п. 29 Стандарта следует, что чистая стоимость такой продукции составит 125 руб. - 100 руб. 5 руб. = 20 рублей. Мы полагаем, что из текста Первого предложения п. 29 ФСБУ “Запасы” должна быть изъята часть фразы после слова “деятельности”. Это придаст фразе большую осмысленность и обеспечит ее сопоставимости с остальным текстом п. 29» [Солодова и др., 2020, с. 136].

Запасы, отличные от готовой продукции и товаров, предлагается оценивать исходя из «их доли в предполагаемой цене готовой продукции, для продажи которой данные запасы предназначены». Целесообразность данного предложения имеет место, однако, исполнение данного требования на практике может быть сопряжено с рядом сложностей. Например, оценить химические соединения с точки зрения их доли в продажной стоимости готовой продукции будет проблематично ввиду использования их в процессе выращивания растений, имеющих различную урожайность и стоимость плодов. Но отметим, что Стандарт предлагает еще один, более простой вариант, заключающийся в определении цены аналогичных объектов, за которую данные объекты предприятие может приобрести на отчетную дату.

Смысл определения чистой цены запасов заключается в возникновении нового объекта учета - резерва под обесценение запасов. Такой резерв создается в случае, если чистая стоимость запаса снизится ниже фактической себестоимости. Мы полагаем, что, придерживаясь в учетной политике требований данного пункта, необходимо допустить нормальное отклонение стоимости, не требующее создание резерва. Цена на объекты запасов может колебаться. Создание резервов под незначительное снижение стоимости представляется не вполне целесообразным. Кроме того, существует такое явление, как сезонное колебание цен, которое также необходимо учесть при разработке учетной политики.

Ряд вопросов возникает и к порядку учета иных объектов, отличных от запасов. Под вопросом остается учет основных средств. Федеральный стандарт «Основные средства» указывает, что он не применяется в отношении животных и растений (за исключением плодоносящих растений). Возникает резонный вопрос, каким документом будет регламентироваться учет основного стада, рабочего скота, племенных животных. Пока что ответов на данные вопросы нормативные документы не содержат. Если рассматривать нормативную базу по бухгалтерскому учету в совокупности, то можно найти информацию, косвенно задевающую данные вопросы. Так, в нормативных документах по бухгалтерскому учету в Российской Федерации в 2020 г. впервые появились такие объекты, как «Биологическая продукция», «Биотрансформация». Но вступивший в силу нормативный документ, раскрывая понятия данных категорий, не отвечает на вопрос, а в чем же будет состоять 
особенность отражения в учете данных объектов бухгалтерского наблюдения. Кроме того, данные понятия раскрываются в ФСБУ ОГС «Запасы», утвержденном приказом Минфина России от 07.12.2018 № 256н, который по определению распространяется только на организации государственного сектора, к которым сельскохозяйственные производители не относятся. Кроме того, объекты, срок использования которых может существенно превышать 12 календарных месяцев, нелогично учитывать как объекты запасов. Такие объекты, как, например, продуктивный скот, используются в течение ряда лет.

Существует еще один вопрос, который до сегодняшнего дня остается нерешенным для сельхозпроизводителей, - это вопрос учета земли. Условия постановки земли на баланс, оценка земли, отражение в учете фактов хозяйственной жизни, связанных с внесением изменений в качество земельного участка. Bce эти вопросы в настоящее время не имеют единого, обоснованного учетным нормативным документом, решения.

\section{Выводы}

Введение новых стандартов бухгалтерского учета и внесение изменений в действующие нормативные документы предполагает необходимость ведения постоянного мониторинга существующей нормативно-правовой базы. Постоянной работой практикующего бухгалтера становится контроль за информацией, появляющейся на официальных сайтах министерства финансов, налоговой службы и т. п. Необходимо осознанно подходить к вопросам возможности и удобства практического применения Стандартов. В локальных нормативных документах организации необходимо предусмотреть процедуру внесения изменений в учетную политику организации, предусматривающую задействование в новой редакции Учетной политики всех произошедших за год изменений.

\section{СПИСОК ЛИТЕРАТУРЫ}

Башкатов, В. В. Учетно-аналитическое обеспечение формирования информационной системы управления сельскохозяйственным производ- ством : монография / В. В. Башкатов. - Краснодар : Изд-во КубГАУ, 2018. - 186 с.

Германова, В. С. Особенности постановки налогового учета в сельскохозяйственных организациях / В. С. Германова // Учет и контроль. 2018. - № 12 (38). - C. 25-32.

Кулиш, Н. В. Развитие учетного обеспечения управления затратами по содержанию и эксплуатации основных средств в сельском хозяйстве / Н. В. Кулиш // Сельское хозяйство - проблемы и перспективы : сб. науч. тр. / под ред. В. К. Пестиса. - Гродно, 2018. - С. 163-173.

Положение по бухгалтерскому учету «Учет материально-производственных запасов» (ПБУ 5) : утв. приказом Минфина РФ от 9 июня 2001 г. № 44н. - Доступ из справ.-правовой системы «Гарант» (http://base.garant.ru/12123639/\#ixzz 6NBXKAAls) (дата обращения: 10.05.2020).

Попова, Л. В. Активизация инновационного процесса в сельском хозяйстве на основе оценки инновационного потенциала агроформирований / Л. В. Попова, П. Холмер // Научное обеспечение устойчивого развития агропромышленного комплекса горных и предгорных территорий : материалы Междунар. науч.практ. конф., посвящ. 100-летию Горского ГАУ. - Владикавказ, 2018. - С. 29-31.

Приказ Минфина России от 15.11.2019 № 180н «Об утверждении Федерального стандарта бухгалтерского учета ФСБУ 5/2019 «Запасы» // Сайт министерства финансов Российской Федерации. - Электрон. текстовые дан. - Режим доступа: https://www.minfin.ru/ru/perfomance/ accounting/accounting/legislation/positions/ (дата обращения: 10.05.2020). - Загл. с экрана.

Солодова, С. В. Отдельные вопросы применения ФСБУ «Запасы» на предприятиях АПК / С. В. Солодова, И. Д. Аникина // Инновационное развитие аграрно-пищевых технологий : материалы Междунар. науч.-практ. конф. / под общ. ред. И. Ф. Горлова. - Волгоград, 2020. - С. 133-137.

Федотова, Г. В. Стратегия развития сельскохозяйственного производства России / Г. В. Федотова, Ц. Цицигэ // Исследование инновационного потенциала общества и формирование направлений его стратегического развития : сб. науч. ст. 9-й Всерос. науч.-практ. конф. с междунар. участием : в 3 т. / отв. ред. А. А. Горохов. - Курск, 2019. - С. 312-315.

Хоружий, Л. И. Бухгалтерский учет готовой продукции в сельском хозяйстве / Л. И. Хоружий, Т. А. Соляник // Перспективные направления научных исследований : сб. ст. по материалам $\mathrm{V}$ ежегод. науч.-практ. конф. - М., 2019. C. 207-214. 
Яценко, И. А. Специфика бухгалтерского учета в сельскохозяйственных организациях: сложности в учете непроизводительных затрат / И. А. Яценко // Научно-методический электронный журнал «Концепт». - 2014. - № S28. C. 66-70.

Alborov, R. A. Biological and land assets in agriculture: development issues of accounting and measurement / R. A. Alborov, S. M. Kontsevaya, S. V. Kozmenkova // Digest Finance. - 2019. Vol. 24, No. 3 (251). - P. 320-328.

\section{REFERENCES}

Bashkatov V.V. Uchetno-analiticheskoe obespechenie formirovaniya informatsionnoy sistemy upravleniya selskokhozyaystvennym proizvodstvom: monografiya [Accounting and Analytical Support for the Formation of an Information System for Agricultural Production Management. Monograph]. Krasnodar, Izd-vo KubGAU, 2018. 186 p.

Germanova V.S. Osobennosti postanovki nalogovogo ucheta v selskokhozyaystvennykh organizatsiyakh [Features of Setting Tax Accounting in Agricultural Organizations]. Uchet $i$ kontrol [Accounting and Control], 2018, no. 12 (38), pp. 25-32.

Kulish N.V. Razvitie uchetnogo obespecheniya upravleniya zatratami po soderzhaniyu i ekspluatatsii osnovnykh sredstv v selskom khozyaystve [Development of Accounting Support for Cost Management for the Maintenance and Operation of Fixed Assets in Agriculture]. Pestis V.K., ed. Selskoe khozyaystvo - problemy $i$ perspektivy: $s b$. nauch. tr. [Agriculture-Problems and Prospects. Collection of Scientific Papers]. Grodno, 2018, pp. 163-173.

Polozhenie po bukhgalterskomu uchetu «Uchet materialno-proizvodstvennykh zapasov» (PBU 5): utv. prikazom Minfina RF ot 9 iyunya $2001 \mathrm{~g}$. № 44n [Accounting Regulation “Accounting for Inventories" (RAS 5). Approved by the Order of the Ministry of Finance of the Russian Federation Dated June 9, 2001 no. 44n]. Access from "Garant" informational and legal web portal. URL: http://base.garant.ru/12123639/ \#ixzz6NBXKAAls (accessed 10 May 2020).

Popova L.V., Kholmer P. Aktivizatsiya innovatsionnogo protsessa $\mathrm{v}$ selskom khozyaystve na osnove otsenki innovatsionnogo potentsiala agroformirovaniy [Activation of the Innovation Process in Agriculture Based on the Assessment of the Innovative Potential of Agricultural
Formations]. Nauchnoe obespechenie ustoychivogo razvitiya agropromyshlennogo kompleksa gornykh i predgornykh territoriy: materialy Mezhdunar. nauch.-prakt. konf., posvyashch. 100-letiyu Gorskogo GAU [Scientific Support of Sustainable Development of the Agro-Industrial Complex of Mountainous and Foothill Areas. Proceedings of the International Scientific and Practical Conference Dedicated to the 100th Anniversary of Gorsk State Agrarian University]. Vladikavkaz, 2018, pp. 29-31.

Prikaz Minfina Rossii ot 15.11.2019 № 180n «Ob utverzhdenii Federalnogo standarta bukhgalterskogo ucheta FSBU 5/2019 «Zapasy» [Order of the Ministry of Finance of Russia Dated November 15, 2019 no. 180n "On the Approval of the Federal Accounting Standard FAS 5/2019 "Inventories"]. Sayt ministerstva finansov Rossiyskoy Federatsii [Website of the Ministry of Finance of the Russian Federation]. URL: https://www.minfin.ru/ru/perfomance/ accounting/accounting/legislation/positions/ (accessed 10 May 2020).

Solodova S.V., Anikina I.D. Otdelnye voprosy primeneniya FSBU «Zapasy» na predpriyatiyakh APK [Selected Issues of Using FSA "Inventories" at Agricultural Enterprises]. Innovatsionnoe razvitie agrarno-pishchevykh tekhnologiy: materialy Mezhdunar. nauch.-prakt. konf. [Innovative Development of Agrarian and Food Technologies]. Volgograd, 2020, pp. 133-137.

Fedotova G.V., Tsitsige Ts. Strategiya razvitiya selskokhozyaystvennogo proizvodstva Rossii [Development Strategy for Agricultural Production in Russia]. Issledovanie innovatsionnogo potentsiala obshchestva $i$ formirovanie napravleniy ego strategicheskogo razvitiya: sb. nauch. st. 9-y Vseros. nauch.prakt. konf. s mezhdunar. uchastiem: $v 3 t$. [Research of the Innovative Potential of Society and the Formation of Directions for its Strategic Development. Collection of Scientific Articles of the 9th All-Russian Scientific and Practical Conference with International Participation. In 3 Vols.]. Kursk, 2019, pp. 312-315.

Khoruzhiy L.I., Solyanik T.A. Bukhgalterskiy uchet gotovoy produktsii v selskom khozyaystve [Accounting for Finished Products in Agriculture]. Perspektivnye napravleniya nauchnykh issledovaniy: sb. st. po materialam $V$ ezhegod. nauch.-prakt. konf. [Perspective Directions of Scientific Research. Collection of Articles Based on the Materials of the $5^{\text {th }}$ Annual Scientific and Practical Conference]. Moscow, 2019, pp. 207-214. 
Yatsenko I.A. Spetsifika bukhgalterskogo ucheta v selskokhozyaystvennykh organizatsiyakh: slozhnosti v uchete neproizvoditelnykh zatrat [The Specifics of Accounting in Agricultural Organizations: Difficulties in Accounting for Non-Productive Costs]. Nauchnometodicheskiy elektronnyy zhurnal «Kontsept»
[Scientific-Methodical Electronic Journal "Concept"], 2014, no. S28, pp. 66-70.

Alborov R.A., Kontsevaya S.M., Kozmenkova S.V. Biological and Land Assets in Agriculture: Development Issues of Accounting and Measurement. Digest Finance, 2019, vol. 24, no. 3 (251), pp. 320-328.

\section{Information About the Authors}

Irina D. Anikina, Doctor of Sciences (Economics), Professor, Head of the Department of Economic Security and Accounting, Volgograd State University, Prosp. Universitetsky, 100, 400062 Volgograd, Russian Federation, anikina@volsu.ru, https://orcid.org/0000-0003-0869-5655

Svetlana V. Solodova, Candidate of Sciences (Economics), Associate Professor, Department of Economic Security and Accounting, Volgograd State University, Prosp. Universitetsky, 100, 400062 Volgograd, Russian Federation, solodovasv@volsu.ru, https://orcid.org/0000-0002-4623-3059

\section{Информация об авторах}

Ирина Дмитриевна Аникина, доктор экономических наук, профессор, заведующая кафедрой бухгалтерского учета и экономической безопасности, Волгоградский государственный университет, просп. Университетский, 100, 400062 г. Волгоград, Российская Федерация, anikina@volsu.ru, https://orcid.org/0000-0003-0869-5655

Светлана Викторовна Солодова, кандидат экономических наук, доцент кафедры бухгалтерского учета и экономической безопасности, Волгоградский государственный университет, просп. Университетский, 100, 400062 г. Волгоград, Российская Федерация, solodovasv@volsu.ru, https://orcid.org/0000-0002-4623-3059 